\title{
The development of computer-assisted instruction game on mirror reflection concepts for junior high school students
}

\author{
Ikmanda Nugraha ${ }^{1}$,, Nida Nusaibah Athfyanti ${ }^{1}$, Harsa Wara Prabawa ${ }^{2}$ \\ ${ }^{1}$ Department of Science Education, Universitas Pendidikan Indonesia. \\ 2 Department of Computer Science Education, Universitas Pendidikan Indonesia \\ Jl. Dr. Setiabudi No.229, Isola, Kec. Sukasari, Kota Bandung, Jawa Barat 40154, Indonesia \\ * Corresponding Author. Email: ikmandanugraha@upi.edu
}

Received: 18 December 2019; Revised: 24 February 2020; Accepted: 11 March 2020

\begin{abstract}
This research aims to develop computer-assisted instruction by using gamification elements on mirror reflection topics in Junior High School. The method used in this research was a descriptive method. The subject of this research are experts and students. Experts chosen in this research are one science expert, one media expert, and one science teacher. Students chosen in this research are fifty-seven students in 9 grade at one of junior high school. The gamification aspects were chosen to make the game were goals, science content, and challenging environment. The expert gave feedbacks in both media and the quality of the content aspects. Students were asked about their agreement level of the gamification elements and the effect of gamification. The effect of gamification asked were motivation, joyness, convenience, addiction, understanding improvement, attractiveness, and interactiveness. The result found that experts gave a good score towards this game. Students also agreed that the game has goals, science content, and challenging environment. The result also found that the gamification elements itself caused them to feel motivated, joy, convenience, addiction, improve their understanding, and attracted after playing the game. Other than that, students confirmed they have two ways of interaction with the game. More than half of total students got a score higher than the average score after playing the game.
\end{abstract}

Keywords computer-assisted instruction, gamification, mirror reflection

How to Cite: Nugraha, I., Athfyanti, N. N., \& Prabawa, H. W. (2020). The development of computer-assisted instruction game on mirror reflection concepts for junior high school students. Jurnal Inovasi Pendidikan IPA, $\quad 6(1), \quad 1-10$. doi:https://doi.org/10.21831/jipi.v6i1.28927

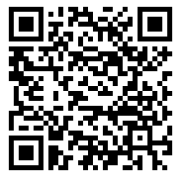

\section{INTRODUCTION}

Physics is one of science subjects that need a high understanding of both application and theoretical. Physics has many roles in daily life, physics education, which are taught and applied effectively at schools is essential (Aykutlu et al., 2015). However, some of the students had difficulties in learning physics (Wosilait et al., 1999). It is also stated that physics is an essential subject because it needs high abstract and conceptual thinking. Learning physics for light especially mirror reflection is one of the topics that require a learning medium because there are subtopics which commonly difficult to be comprehended by students by only seeing the real result (Ernawati, 2013; Fernandes, 2016).

The experience that was created by the teacher affects how the students get a science concept in science learning in the class (Wosilait et al., 1999). Teachers gave the conventional way because the teacher itself got difficulties in delivering physics material (Arkün \& Akkoyunlu, 2008). The newest Indonesia curriculum of education that there is change given from the previous curriculum which is the learning process. Learning process used in curriculum 2013 that students no longer given material directly by the teacher, but the students will be the one who seeks the knowledge.

Technology is increasing rapidly, today's information and communications technologies can be applied to science education to make and create student-centered learning and focus on the virtual experience. computer-assisted instruction (CAI) plays an important role in contemporary teaching and learning of science concepts (Chang, 2001). Computer use in an educational setting is the most popular and well known. He also stated that there is Computer-assisted instruction (CAI) that can play an important role in teaching science concepts. Computers can speed up and extend people's ability to collect, store, compile, and analyze data, prepare research reports, and share data and ideas with 
investigators all over the world. Computer-based and internet as new technologies help teachers by providing interesting tools that can be used to improve the teaching-learning process.

Computer-assisted instruction (CAI) is a method of instruction that uses the computer as a tool to meet the needs of individual learners (Anderson, 1986). CAI is a tool facilitate to make the interaction between humans and machines, which is a computer, in two-way interaction. The objective of CAI is to create a learner-centered environment. The process given while using CAI is when learners create interaction with the computer, information and a stimulus is presented on monitors, and feedback will be received by the learners.

To maximize the features and create an attractive platform for the students, gamification elements applied in this research. The integration between gamification and computer-assisted instruction theory will create innovation in science teaching-learning that will be adjusted to the current modern condition. Gamification, from the English "gamification" is the concept of applying game principles and mechanics in non-gaming activities, particularly in education (Kirillov et al., 2016). Gamification will be really useful to enhance students learning motivation. Thus, willingness is also impacting how students understand the materials. Also, there are many ways to create a gamification concept in education which will help both many stakeholders especially teachers to deliver their teaching method.

Gamification is the use of game design elements, game thinking, and game mechanics to enhance non-game contexts and the main function that gamification could provide - enhancing a situation through the use of gaming mechanics, the benefits which include increased engagement, higher motivation levels, increased interaction with the user, and greater loyalty (Shapiro et al., 2014).

The purpose of gamification is the process of game-thinking and game mechanics to engage users and solve problems (Zichermann \& Cunningham, 2011). In a bigger perspective, learning for children by turning the experience into a game, including some reward for achievement, it can produce unprecedented behavior change. There are four types of the positive impact that video games have on the kids who play them: cognitive, motivational, emotional, and social different with the stigma about the game was always negative (Shapiro et al., 2014).

Using games not only offers engaging opportunities for young students to acquire important academic skills but it also teachers those students to associate screens with refined cognitive skills (Buckley \& Doyle, 2016). gamification impacts students with different types of motivation differently. The results demonstrate that it is particularly effective for students who are intrinsically motivated, particularly either by a motivation to know or a motivation towards stimulation (Sung \& Hwang, 2013).

Thus, this research will be about developing computer-assisted instruction by using gamification elements into tools in physics topics that need abstract thinking such as understanding mirror image and reflection in junior high school. To solve problems of delivering physics content in good ways by virtual experience and student-centered learning. The game will give several advantages such as motivation, joy, convenience, while also improving students understanding in the mirror reflection.

This study tries to answer the following questions: (1) How is the design and development of computer-assisted instruction by using gamification elements in learning mirror reflection in Junior High School? (2) How does the respond of experts on content, language, and media of computer-assisted instruction development by using gamification elements in learning mirror reflection in Junior High School? (3) How do teachers respond to content, language, and media of computer-assisted instruction development by using gamification elements in learning mirror reflection in Junior High School? (4) How do students respond to gamification elements and gamification effects on learning mirror reflection in Junior High School?

\section{METHOD}

The method used in this research is a descriptive study. This method described as very detailed and careful statements given (Fraenkel et al., 2012; Mihardi et al., 2010). The subjects for this research consist of experts and students. The experts in this research are one science field expert, one media field expert, and one science teacher. The experts have the role and contribution to enrich the quality of the game and ensuring the appropriateness of the material. The expert on science had an educational background until doctoral and has experience in teaching science. The expert on media had experience in being a lecturer for subjects' media and robotics. The teacher in this research had a background of eight years' experience teaching science in junior high school. 
There are also fifty-seven students as another subject, that consist of 28 male students and 29 female students in 9 grades in one of junior high school. The location of research is one of school that adjusts technology as one of their subjects, thus the students do not need to learn technology or computer from the very beginning again since this study has objective to adjust their learning and subject test. Data was taken in a computer laboratory in school which had nineteen computers available and can be normally operated.

The choice of students uses simple random sampling in 9 grade at one of junior high school. The simple random sample is one method stated that every member of the population has an equal and independent chance of being selected. If there is a large sample, this method is the best way to obtain a sample representative of the population of interest (Fraenkel et al., 2012).

The data is collected in the form of rubrics from experts and a survey from the students. The rubrics and survey have a scale, rating, and written review. The rubrics have one until four scales with each specific description on the scale. The survey was given both yes or no choice and level of agreement scale 1-5. The written review contains a form to put feedback, comment, opinion, and suggestions.

For the experts, the instrument that consists of game, video explanation, rubrics were directly given to experts of science, media, and teacher directly after the game was created. The game was in the form of an EXE type so the experts can try it directly. All of the experts were asked to play the game from a computer and laptop, depend on the condition. Then, after trying one game, experts filled the rubrics given. Experts gave feedback and opinion written and verbal to the researcher while asking some questions for clarity. The data collected from experts were in the form of scale and suggestions or comments regarding the aspects and general feedback towards the game.

The output data collected from students are the percentage of yes/no, level of agreement, and written comment or feedback. The first process took the data that, the game and video manual were copied and tried one by one to seventeen computers in the school one day before taking the data. Students were being separated into three batches to collect fifty-seven data because of computer limitations. Students got into the class, and the worksheet was given to each of the students. The worksheet consists of the manual to play the game and the questionnaire. Then, the researcher explained how to play the game each of the processes one by one using the video manual explanation in front of the class. Students were also explained how to fill the questions. After that, students played the game by themselves. There were time differences in each student to finished the game. Some of the students asked so many things in the middle of playing the game to the researcher. Then after all of the students finished the game, in around 30-45 minutes, the filled questionnaire was given back to the researcher. Data collected in the form of scale, ratings, and answers of the quiz they answer in one worksheet for each student.

\section{RESULTS AND DISCUSSION}

\section{Game Production}

The game produced by using software Construct 2 for educational purposes. The process of creation is inserting objects, adding behaviors, adding events, adding game functionality, keeping score, finishing touches. The process creation of Construct 2 is shown in Figure 1. In the main menu, there are the stage or world that they can play in this game which are Flat World, Spherical World and Puzzle World. This surface also has the score, and they can reset the score or the name. The page is shown on Figure 2.

The first game is Flat World, it is about a flat mirror concept, students will learn about reflection and how the angle shows. Students can open the worksheet before playing the game. After the student finishes the first stage, students will be directed to the main menu with the second world that can be clicked by them. This second stage or Spherical World, the students will learn about the spherical or curved mirror, how properties and characteristics of a curved mirror. After students finish the second game and get a score for each stage, the student can go to the next stage and start to play the game. In Puzzle World Game., the student will have to move two mirrors in order to put the light to the gem. This game need 600 second to finish and they need to get 25 points, and right after they get the gem, there will be pup up message showing. There will be two questions to assess all mirror reflection concept in the end of the game. 
Jurnal Inovasi Pendidikan IPA, 6 (1), 2020 - 4

Ikmanda Nugraha, Nida Nusaibah Athfyanti, Harsa Wara Prabawa

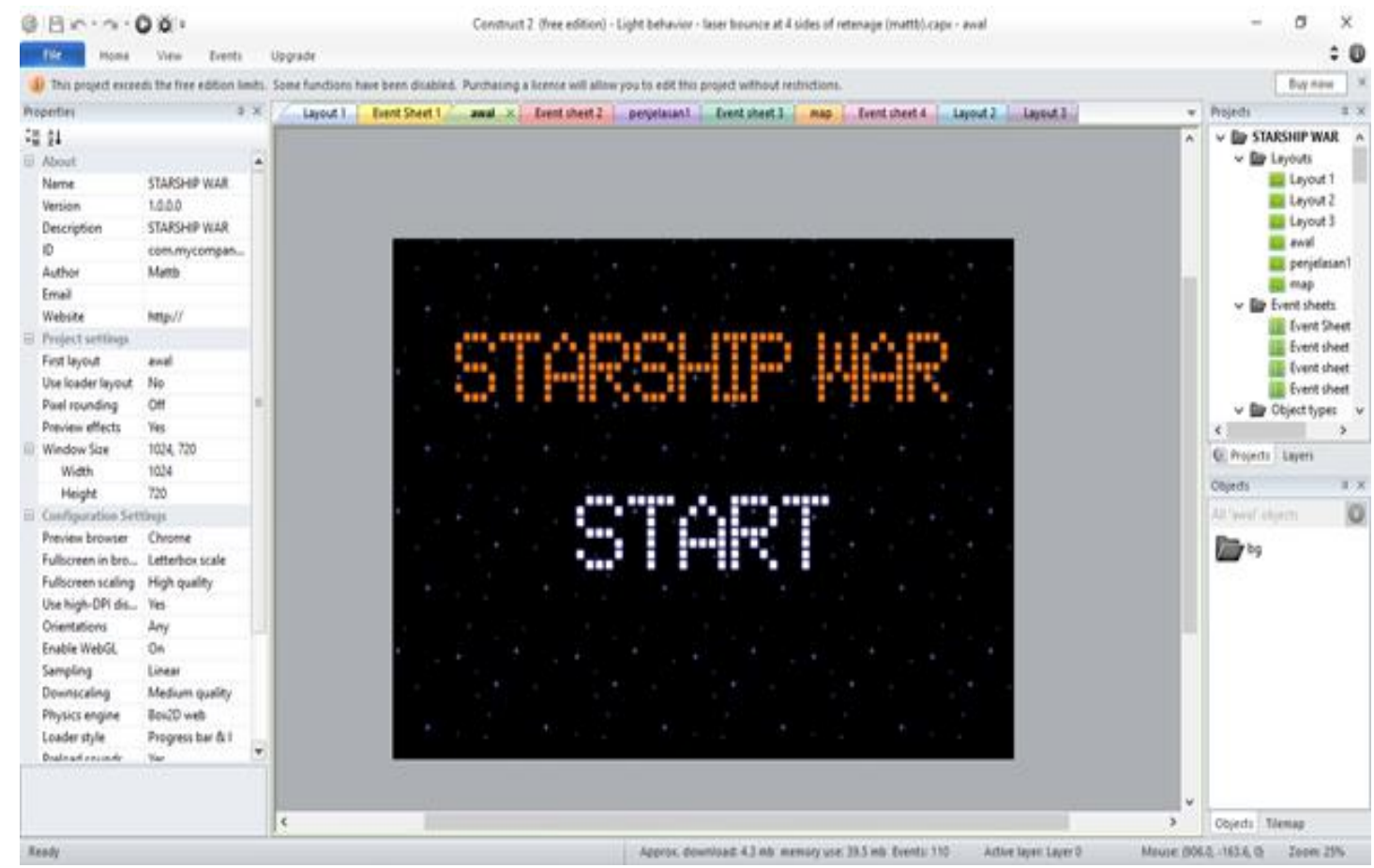

Figure 1. Game construction in a software called Construct 2 for educational purposes

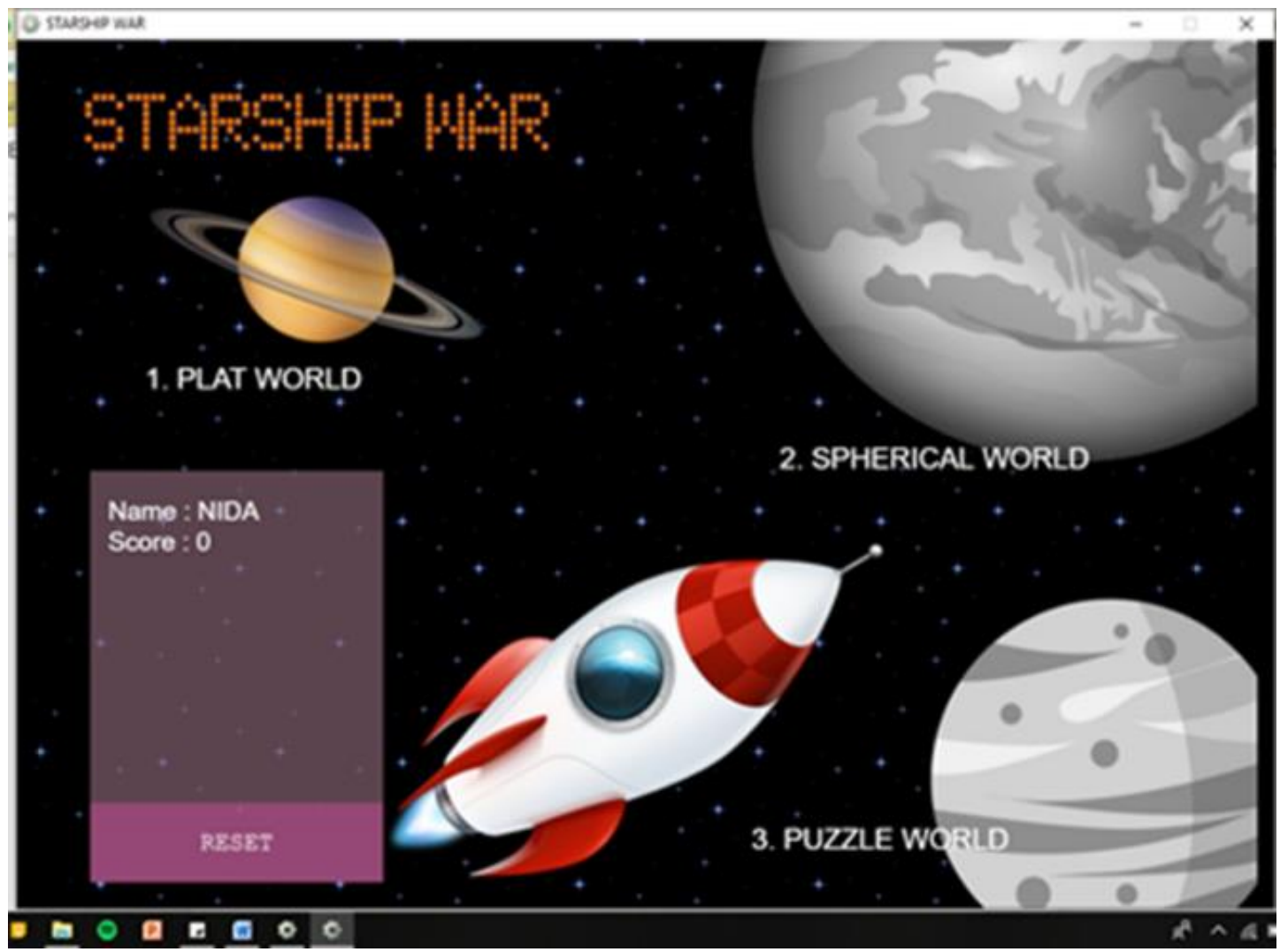

Figure 2. Main menu of the game

\section{Expert's Responses}

In order to check the development of learning, media created based on the gamification aspect a multimedia rubrics consist of the indicator, criteria, and aspects for scale one until 4 . The scale one until 4 has its category and definition for each criterion. Thus the expert can choose the most suitable point based on the condition of the game and their perspective. The score was counted by using average in 
Jurnal Inovasi Pendidikan IPA, 6 (1), 2020 - 5

Ikmanda Nugraha, Nida Nusaibah Athfyanti, Harsa Wara Prabawa

each aspect and indicators from all experts. There is also an average score of all experts from all of the indicator. The average score for each indicator is shown in Figure 3.

\section{Average Score Experts Judgemet}

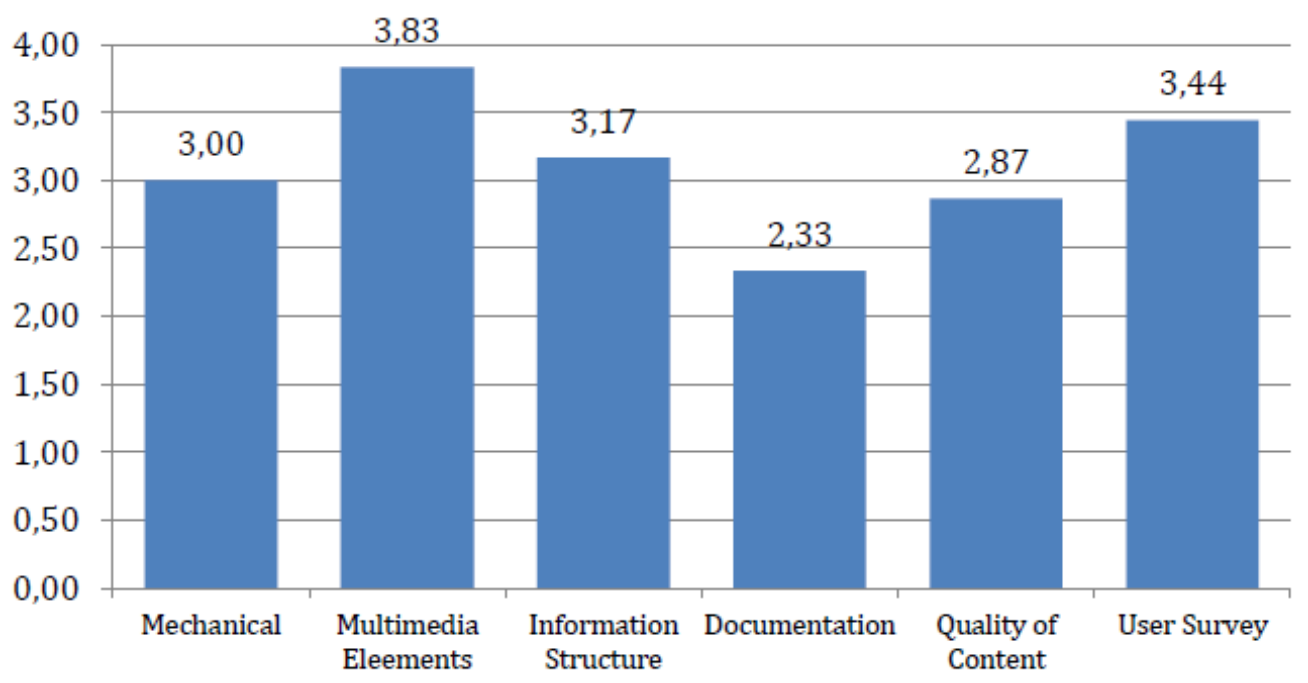

Figure 3. Expert's Respond Chart

The Figure 3 showing the average in each indicator and the lowest average percentage is documentation which consists of citing resource and permissions obtained for resources. The second-lowest average percentage is mechanical which score is 3.00 that consists of technical is navigation, spelling \& grammar, and completion. From the responses given by the experts, it can be analyzed that for both science and media expert their suggestion and feedback are more into the theoretical and media elements, the way game works, while the teacher responds was about the application in real life when delivering learning to the students.

One of the respond from an expert was about some bugs happening in part of the game which is actually the picture was once not moving in the second world stage. The highest average percentage is multimedia elements which have 3.85 scores that consist of screen design and use of enhancement which most of the experts give score 4 and said -it has a combination of multimedia elements and content takes communication to a superior level. There is clear attention given to balance proportion, harmony, and restraint. The synergy reaches the intended audience with style.

One of the requirements for computer-assisted instruction standard to meet curriculum objectives are record keeping, graphics, color, sound, expandability and the appearance on the video display must be uncluttered and readable (Anderson, 1986). It matches with the game that is created with the highest score of expert average is the multimedia element. The multimedia element mentioned on the rubrics are mechanical that consist of the screen design, appearance, and graphics, information structure, and documentations. It is also stated that each frame ends with a question that the student must answer before going on to the next frame, which is also available in the game. The result of expert rubrics and statement from the previous result were all matched.

\section{Students' Responses}

In order to check the development of computer-assisted instruction by using gamification learning media based on students' perspective, one of the questionnaires were given to the students by creating questions yes or no. The questionnaire was asking the availability of the gamification elements which are clear goals, mirror reflection understanding, containing mirror reflection, level or challenge, clear screen design, language error, navigation error, difficulties. The surveys were collected from 57 students in 9 grades. Students 'responses is given in Figure 4.

All of the good aspects that confirmed "yes" to clear goals, understand mirror reflection, level or challenge, clear screen design and "no" to language error, navigation error, and difficulties were added up to become one percentage which resulted in $89 \%$ availability of the aspects mentioned in Figure 4. From the result, it is explained by the survey gave that 55 students $(96 \%)$ think the game has given them a clear goal to finish the game. 51 students (89) think the game helped them to understand new material 
Jurnal Inovasi Pendidikan IPA, 6 (1), 2020 - 6

Ikmanda Nugraha, Nida Nusaibah Athfyanti, Harsa Wara Prabawa

about mirror reflection and image. 56 students $(98 \%)$ agreed that the game contained learning about mirror reflection in a plane, and a spherical mirror. 54 students $(94 \%)$ think that each of the stages or world in this game has a different level of difficulties. 55 students $(96 \%)$ think that the game has a clear screen or design. 47 students (82\%) think that the game has not many language errors. 48 students $(84 \%)$ think that the game has not many error navigations that cannot work out in the game. 38 students (67\%) think that they did not find any difficulties while playing the game.

\section{Gamification Elements Availability}

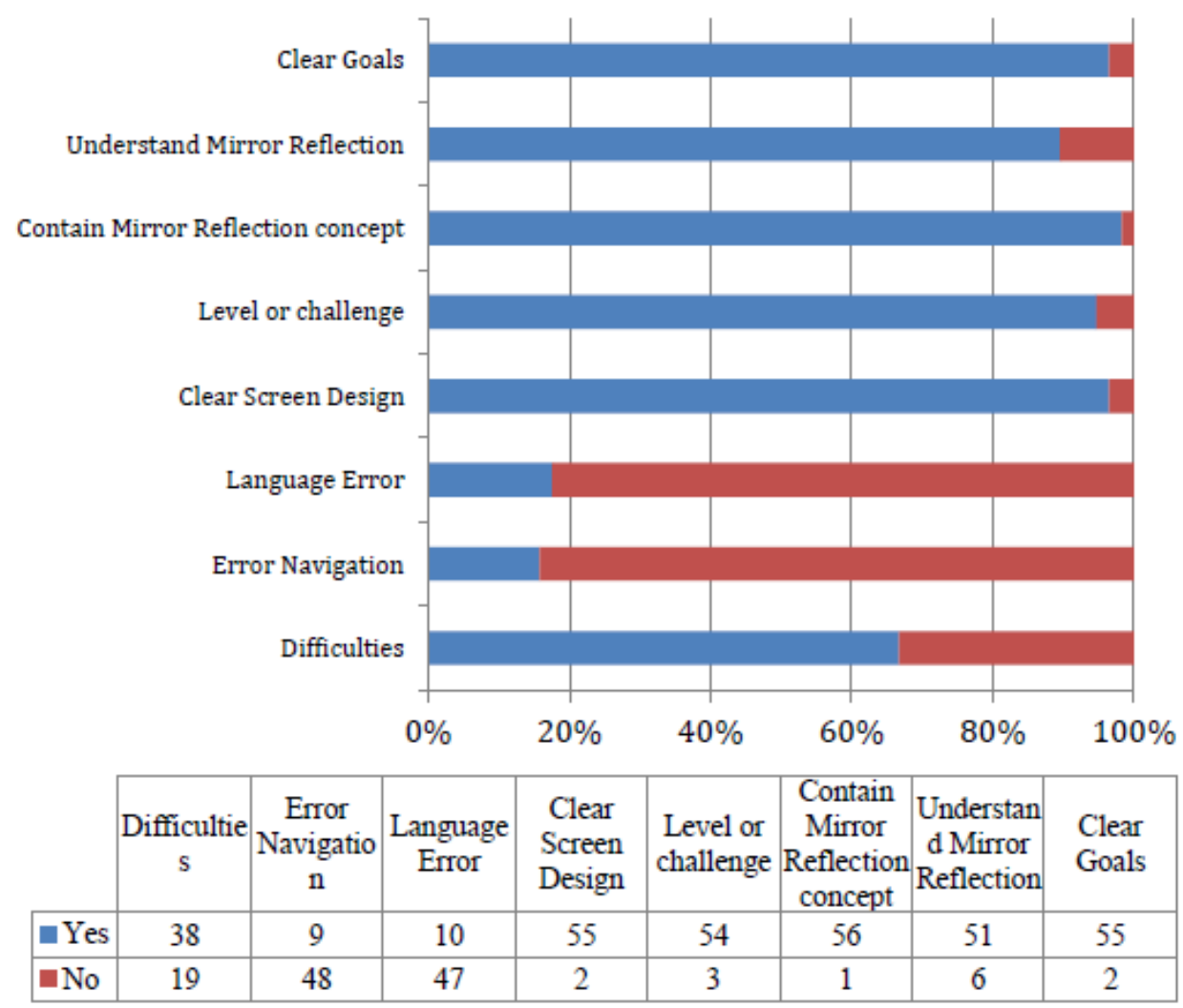

Figure 4. Students 'response towards Gamification Elements

The lowest score of students' responses is about the difficulties found by the students. There are $38(68 \%)$ of the result said they found difficulties when playing the game. The difficulties that come are predicted from experts 'judgment where the instruction is not clear and the trial time for the students to try and understand the game first before directly play the game is not provided. The result is also caused because of some major error in mechanical, technical and navigation error that is also stated by two experts. The example of major error was in a flat world when the laser should not be shot anywhere when students still playing. Another major error is when the time keeps decreasing while students still read and understand pop up material or while students answer the questions.

Gamification studies show positive effects/results in motivational affordance (Hamari et al., 2014). It is also stated that motivational affordance tested consisted of several variants which are points, leaderboards, achievements/badges, levels, story/theme, clear goals, feedback, rewards, progress, and challenge. After asking the availability, in order to see how gamification effects to several aspects which are interactiveness, attractiveness, improve understanding, addiction, convenience, and motivation for students, data was collected from the survey given to the students and being analyzed by the level of agreement Likert Scale.

From one of the researches, computer-assisted instructional by using interactive animation is more effective in teaching science concept while teaching physics concept that seems too abstract (Abd Rahman et al., 2014). Students' level of agreement response is given as following in Figure 5.

Figure 5. shows students' agreement on the availability of several aspects that should be created in this learning media using gamification, which is content understanding, a clear goal, and a challenging 
Jurnal Inovasi Pendidikan IPA, 6 (1), 2020 - 7

Ikmanda Nugraha, Nida Nusaibah Athfyanti, Harsa Wara Prabawa

environment. It is found that students mostly agree and strongly agree that the game impact on those aspects after students playing the game. Less than $6 \%$ of students disagree or strongly disagree with the aspects given.

\section{Students' Level of Agreement on Gamification Elements}

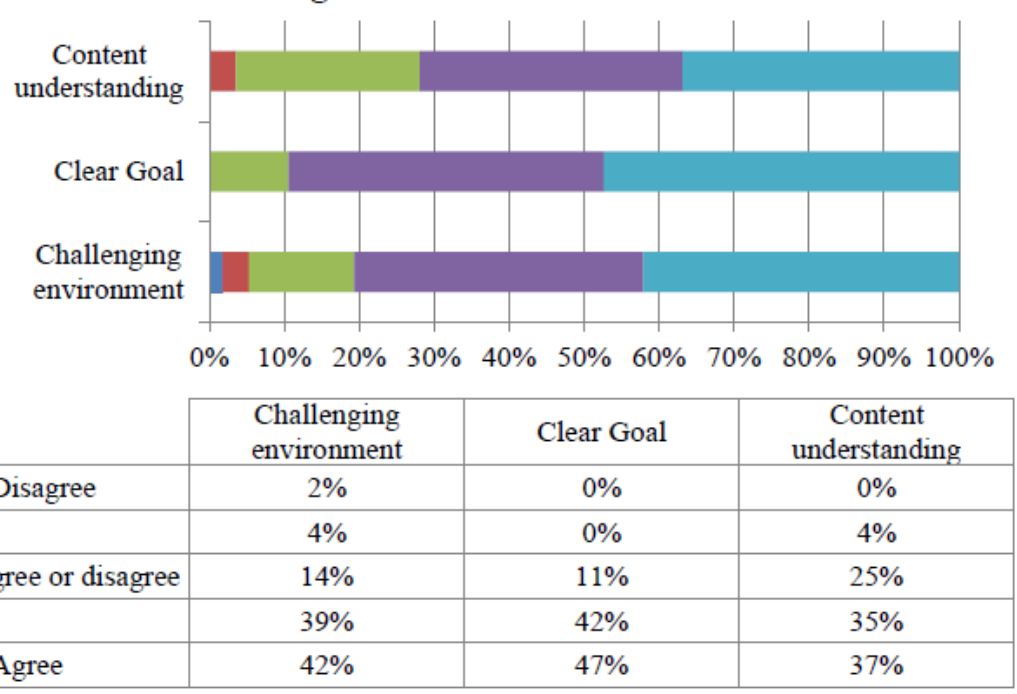

Figure 5. Students Level of Agreement towards Gamification Elements Availability

The students also asked about the effect happened after they play the game which consists of interactiveness, attractiveness, improve understanding, addiction, convenience, joyness, and motivation. The result is shown in Figure 6.

\section{Students' Level of Agreement on Gamification Effect}

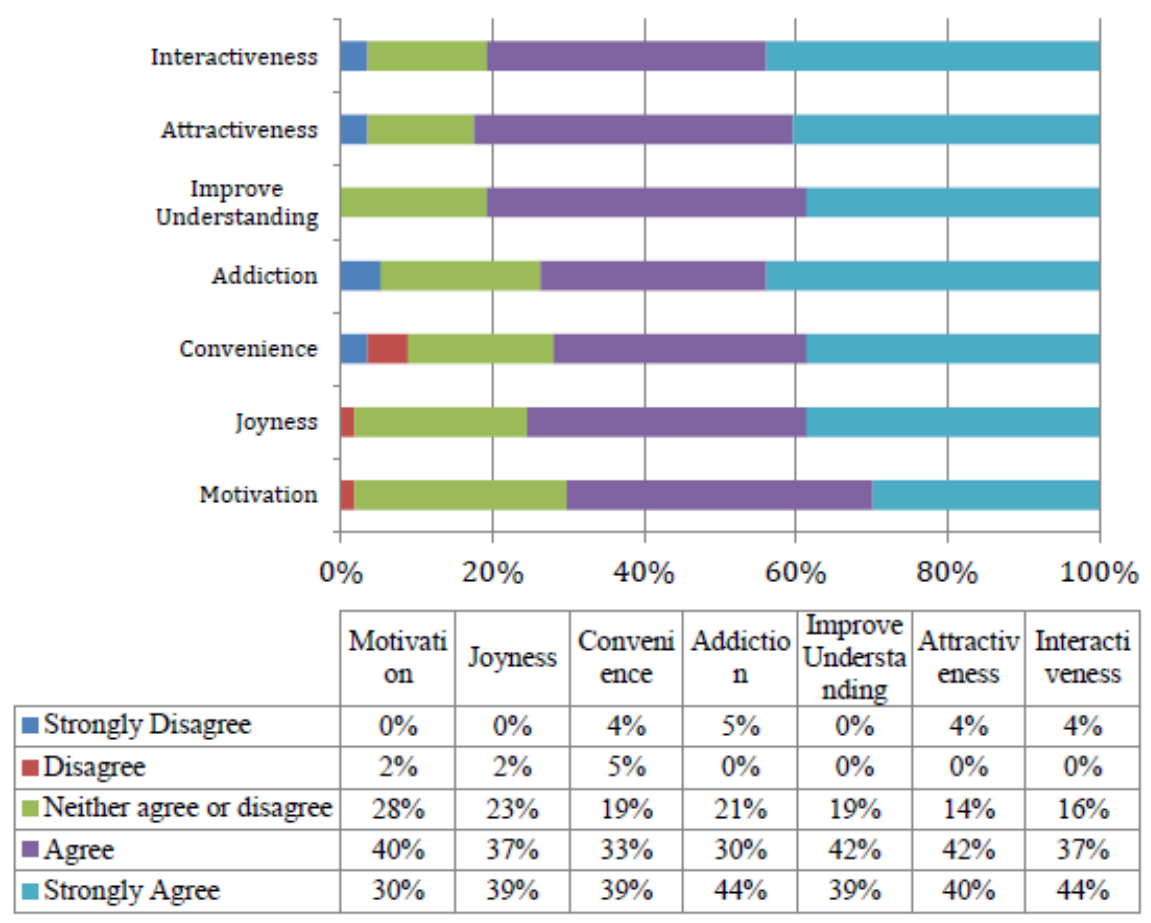

Figure 6. Students 'level of agreement towards gamification Effect

From all of the aspects of the data, the percentage is given in Figure 6. Above with meaning the leftmost is strongly disagree and rightmost is strongly agree on percentage result. All of the aspects got mostly dominant in agreeing and strongly agree on the level. In an interactive and addictive aspect, $44 \%$ of 57 students found out that this game is causing interaction and addiction for them to play. In 
improving the understanding aspect, $42 \%$ of the students are also agree that this game improved their understanding of image formation in the flat, convex, and concave mirror. This agreement level also will straighten out the aspect availability of the science content in students' availability survey that they are aware of popup science concepts given for each of the world and stage was meaningful to understand science concept of mirror reflection. The same with that, in the attractiveness aspect, $42 \%$ of the students found out that this game is also attractive to play.

In the motivation aspect, students are also agreed that $40 \%$ of them get motivation and $30 \%$ of them strongly agree to learn physics after playing this game. The data showed that most of the students strongly agree that this game causes them these aspects motivated, joy, convenience, addicted, improved their understanding, attracted, and interacted in their learning process. The statement is supported that students will enjoy the game because there is a point system, leaderboards, player profiles, teams, progress bars, and achievement badges in the media (Cheong et al., 2014).

However, there are also some of the people who do not feel the same way or they strongly disagree, disagree, or neither disagree or agree. It happened because of some cases in the system was not motivating enough for several students because they might think it is not fun to compete with their classmate. Other reasons also because there are four types of player based on performance and mastery level. There are four types of players based on performance and mastery levels of achievement goals, which are performance-only players, mastery-only players, non-achievers, and superachievers (Heeter et al., 2011). But there are other styles of the player which are socializers or explorers, which in brief these players do not like competition but like it to be more sociable fir socializers, and only care about unlocking the game for the explorers (Kumar et al., 2017).

\section{Students' Performance Result}

In the game, students were asked to answer some questions given; there are two questions that students need to answer in each stage/world that makes a total of nine questions (two for a flat world. two for the spherical world. two for the puzzle world. and three for the last assessment). Students ${ }^{6}$ score were collected and counted for each person, and the average of students' scores is 42.9 .

The Figure 7 shows the percentage of student score compared to the average score from all of the students. $61 \%$ of the students get to score more than average, which indicates the agreement level in student survey also being supported by the achievement of the students. This data indicates that the science material about mirror reflection given to the students was understandable. The rest of $39 \%$ students get a score lower than the average. That indicates there still need improvement in the game content or questions because 13 of students got 33.3, six students got 22.2, one student got 1, and two students got 0 .

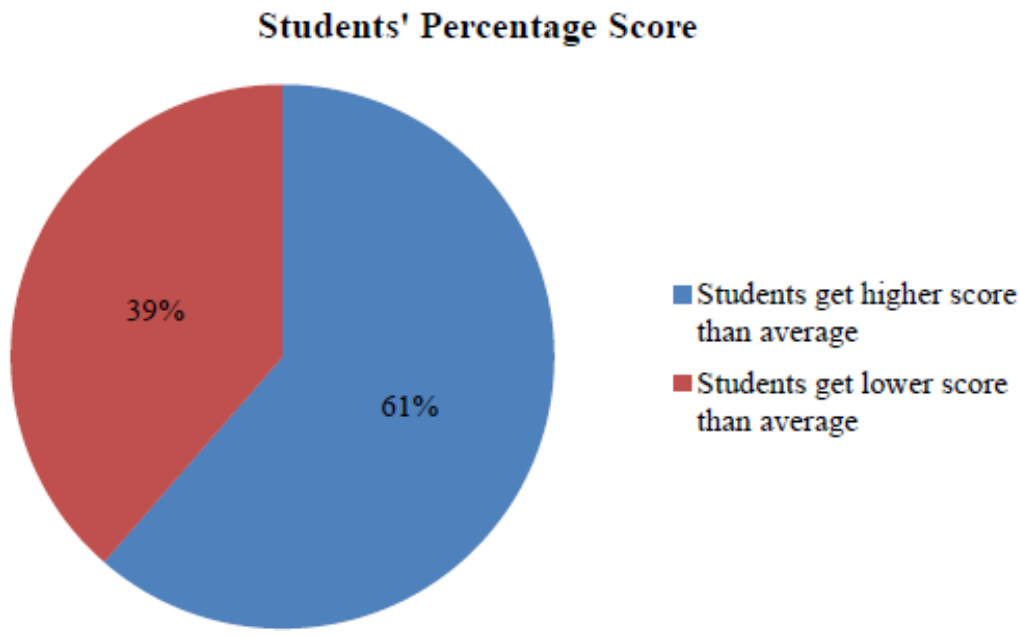

Figure 7. Students Percentage Score on Assessment

Gamification activity can help to develop practical competence but also hinder understanding of the theoretical concept (Domínguez et al., 2013), which also shown in this research that the result of the students ' performance when the students get a good grade in the application after they play the game of 
reflection, in spherical worked they got not really good score since it is all about theoretical rather than something is shown in the game.

\section{CONCLUSION}

It can be concluded that experts are all said that this game created was creative, new, and original. The expert also said that CAI can help students and can be implemented at science class in junior high school to learn about mirror reflection. Gamification aspects that are being focused on this research were clear goals, content understanding, and challenging environment. More than $70 \%$ of the students agreed and strongly agreed to the aspects assessed. The gamification aspects created students get the effects that are motivated, joy, convenient, addicted, understanding improved, attracted, got interacted. More than half of students got an assessment score more than the average score from on all of the assessments.

\section{REFERENCES}

Abd Rahman, M. J., Ismail, M. A. H., \& Nasir, M. (2014). Development and evaluation of the effectiveness of computer-assisted physics instruction. International Education Studies, 7(13), 14-22. https://doi.org/10.5539/ies.v7n13p14

Anderson, K. (1986). Computer-assisted instruction. Journal of Medical Systems, 10(2), 163-171. https://doi.org/10.1007/BF00993122

Arkün, S., \& Akkoyunlu, B. (2008). A Study on the development process of a multimedia learning environment according to the ADDIE model and students' opinions of the multimedia learning environment. Interactive Educational Multimedia, 17, 1-19. https://revistes.ub.edu/index.php/IEM/article/view/11902

Aykutlu, I., Bezen, S., \& Bayrak, C. (2015). Teacher opinions about the conceptual challenges experienced in teaching physics curriculum topics. Procedia - Social and Behavioral Sciences, 174, 390-405. https://doi.org/10.1016/j.sbspro.2015.01.681

Buckley, P., \& Doyle, E. (2016). Gamification and student motivation. Interactive Learning Environments, 24(6), 1162-1175. https://doi.org/10.1080/10494820.2014.964263

Cheong, C., Filippou, J., \& Cheong, F. (2014). Towards the gamification of learning: Investigating student perceptions of game elements. Journal of Information Systems Education, 25(3), 233. https://jise.org/volume25/n3/JISEv25n3p233.html

Domínguez, A., Saenz-de-Navarrete, J., De-Marcos, L., Fernández-Sanz, L., Pagés, C., \& MartínezHerráiz, J.-J. (2013). Gamifying learning experiences: Practical implications and outcomes. Computers \& Education, 63, 380-392. https://doi.org/10.1016/j.compedu.2012.12.020

Ernawati, E. (2013). Penerapan strategi Mind Mapping untuk meningkatkan kemampuan menulis kreatif cerpen berdasarkan pengalaman orang lain siswa kelas X SMA Negeri I Talun Kab. Blitar [Universitas Negeri Malang]. http://repository.um.ac.id/57962/

Fernandes, C. A. (2016). Penerapan strategi mind mapping untuk meningkatkan pemahaman konsep fisika siswa pada materi alat-alat optik. Inovasi Pendidikan Fisika, 5(3). https://jurnalmahasiswa.unesa.ac.id/index.php/inovasi-pendidikan-fisika/article/view/21854

Fraenkel, J. R., Wallen, N. E., \& Hyun, H. H. (2012). How to design and evaluate research in education. McGraw-Hill Humanities/Social Sciences/Languages.

Hamari, J., Koivisto, J., \& Sarsa, H. (2014). Does gamification work? -- A literature review of empirical studies on gamification. 2014 47th Hawaii International Conference on System Sciences, 30253034. https://doi.org/10.1109/HICSS.2014.377

Heeter, C., Lee, Y.-H., Magerko, B., \& Medler, B. (2011). Impacts of forced serious game play on vulnerable subgroups. International Journal of Gaming and Computer-Mediated Simulations, 3(3), 34-53. https://doi.org/10.4018/jgcms.2011070103

Kirillov, A. V, Vinichenko, M. V, Melnichuk, A. V, Melnichuk, Y. A., \& Vinogradova, M. V. (2016). Improvement in the learning environment through gamification of the educational process. International Electronic Journal of Mathematics Education, 11(7), 2071-2085. https://www.iejme.com/article/improvement-in-the-learning-environment-through-gamification- 
Jurnal Inovasi Pendidikan IPA, 6 (1), 2020 - 10

Ikmanda Nugraha, Nida Nusaibah Athfyanti, Harsa Wara Prabawa

of-the-educational-process

Kumar, J. M., Herger, M., \& Dam, R. F. (2017). Bartle's player types for gamification. Interaction Design Foundation. https://www.interaction-design.org/literature/article/bartle-s-player-typesfor-gamification

Mihardi, S., Harahap, M. B., \& Sani, R. A. (2010). The effect of project based learning model with KWL worksheet on student creative thinking process in physics problems. Journal of Education and Practice, 4(25), 188-200. https://www.iiste.org/Journals/index.php/JEP/article/view/9086

Shapiro, J., Tekinbaş, K. S., Schwartz, K., \& Darvasi, P. (2014). MindShift guide to digital games+ learning. Games and Learning Publishing Council.

Sung, H.-Y., \& Hwang, G.-J. (2013). A collaborative game-based learning approach to improving students' learning performance in science courses. Computers \& Education, 63, 43-51. https://doi.org/10.1016/j.compedu.2012.11.019

Wosilait, K., Heron, P. R. L., Shaffer, P. S., \& McDermott, L. C. (1999). Addressing student difficulties in applying a wave model to the interference and diffraction of light. American Journal of Physics, 67(S1), S5-S15. https://doi.org/10.1119/1.19083

Zichermann, G., \& Cunningham, C. (2011). Gamification by design: Implementing game mechanics in web and mobile apps. "O'Reilly Media, Inc." 